\title{
FAKTOR EKSTERNAL PENYEBAB TERJADINYA KARIES GIGI PADA ANAK PRA SEKOLAH DI PAUD STROWBERRY RW O3 KELURAHAN BANGETAYU WETAN KOTA SEMARANG TAHUN 2016
}

\author{
Miftakhun N.F $^{1}$, Salikun $^{\varpi^{2}}$, Lanny Sunarjo ${ }^{3}$, Erni Mardiati ${ }^{4}$
}

\begin{abstract}
ABSTRAK
Karies gigi adalah penyakit jaringan gigi yang ditandai dengan kerusakan jaringan, mulai dari permukaan gigi meluas ke arah pulpa. Proses terjadinya karies gigi dapat disebabkan oleh faktor eksternal, yaitu lingkungan, perilaku, pelayanan kesehatan dan keturunan. Masalah yang ada pada PAUD Strowbery $71 \%$ anak memiliki karies gigi. Penelitian ini bertujuan untuk mengetahui faktor eksternal penyebab terjadinya karies gigi pada anak pra sekolah di PAUD Strowberry.

Jenis penelitian yang digunakan adalah deskriptif kuantitatif dengan rancangan Cross sectional. Sampel pada penelitian ini menggunakan metode total sampling yaitu mengikutsertakan seluruh populasi siswa PAUD Strowberry yang terkena karies, yaitu sebanyak 34 anak. Pengumpulan data pada penelitian ini menggunakan pembagian kuesioner kepada orang tua. Kuesioner yang digunakan pada penelitian ini sebelumnya telah melalui uji validitas dan reliabilitas yang dilakukan pada 20 responden orang tua di PAUD Kasih Ibu RW 02. Metode analisa data yang digunakan menggunakan perhitungan statistik dengan menggunakan uji Odds ratio.

Hasil penelitian menunjukkan bahwa pengetahuan buruktentang gigi berlubang sebesar 71\%, sikap yang buruk tentang menyikat gigi sebesar $65 \%$, praktik/tindakan yang buruk tentang penyebab gigi berlubang sebesar $76 \%$, lingkungan yang buruk tentang kondisi lingkungan keluarga sebesar $62 \%$, pelayanan kesehatan yang buruk tentang pengalaman pengobatan sebesar 68\%, keturunan yang kurang baik tentang gigi berlubang sebesar $65 \%$. Dalam penelitian ini dapat disimpulkan bahwa pengetahuan merupakan faktor yang paling dominan dalam mempengaruhi terjadinya karies gigi pada anak pra sekolah di PAUD Strowberry. Maka dari itu sebaiknya orang tua selalu menjaga kesehatan gigi anak dengan menyikat gigi 2 kali sehari.
\end{abstract}

Kata kunci : Karies Gigi, Faktor Eksternal, Anak-anak

\begin{abstract}
Dental Caries is a disease that attacks the dental tissue by damaging the tissue starts from the tooth surface and spread to pulp. Some external factor provokes dental caries are the environment, behaviour, heath care and heredity. $71 \%$ preschoolers at PAUD Strowberry have dental karies. This research is to understand the factor that causes dental caries towards preschoolers at PAUD Strowberry.

This research uses quantities descriptive with cross sectional to write the essay. Using totalsampling method for searching the sample includes the sum of the preschoolers at PAUD Strowberry that are infected by dental caries. There are 34 preschoolers that have dental caries. Using questionnaire method to the preschooler's parents to gather the information for the research we need. The validation and the reliability of the information from the questionnaire has been testedby 20 of the preschooler's parents at PAUD KasihIbu $R W$ 02. The method to analysis the information using Odds ratio.

The result showed the ignorance about dental caries is $76 \%$, bad attitude while brushing teeth is $65 \%$, bad action about causes dental caries is $76 \%$, unhealthy environments for the family is $62 \%$, the ignorance of health care about curing is 68\%, and unhealthty heredity about dental caries is $65 \%$. It can be concluded from this research is the knowledge of the disease it the main element that cause dental caries towards preschoolers at PAUD Strowberry. So, the parents should take care therekids teethby brushing their teeth twice a day.
\end{abstract}

Key words : Dental Caries, External Factors, Children

1) Mahasiswa Jurusan Keperawatan Gigi Poltekkes Kemenkes Semarang

${ }^{2,3,4)}$ Dosen Jurusan Keperawatan Gigi Poltekkes Kemenkes Semarang

$凶:$ Salikun62@gmail.com 


\section{PENDAHULUAN}

Masalah kesehatan gigi di Indonesia masih sangat perlu penanganan lebih lanjut. Hasil Riskesdas 2013 menunjukkan bahwa prevalensi nasional masalah gigi dan mulut dijumpai sebesar 25,9 \% (Depkes, 2013). Masalah kesehatan gigi dan mulut yang paling banyak diderita masyarakat Indonesia salah satunya adalah karies gigi.Berdasarkan studi pendahuluan yang telah dilakukan pada siswa PAUD Strowberry RW 03 Kota Semarang diperoleh data masalah tahun 2015 yaitu kasus karies gigi menjadi salah satu permasalahan penyakit gigi dan mulut yang tinggi. Dari total 48 siswa yang diperiksa didapatkan 34 anak (71 \%) dengan gigi karies. Berdasarkan data profil kesehatan kota Semarang tahun 2014, menunjukkan bahwa sebanyak $48 \%$ anak sekolah yang telah mendapatkan perawatan, sedangkan $52 \%$ anak belum mendapatkan perawatan (Dinkes Kota Semarang, 2015). Berdasarkan keterangan dari pihak PAUD Strowberry RW 03 Kelurahan Bangetayu Wetan bahwa belum pernah dilakukan pemeriksaan oleh tenaga kesehatan di PAUD Strowberry RW 03 Kelurahan Bangetayu Wetan sehingga kemungkinan kasus gigi dan mulut akan banyak ditemukan.

Prioritas masalah kesehatan gigi dan mulut pada siswa PAUD Strowberry RW 03 Kota Semarang menggunakan metode USG (Urgency Seriousness Growth). Berikut adalah tabel prioritas masalah kesehatan gigi digambarkan pada Tabel 1

Tabel 1. Penentuan Prioritas Masalah USG

\begin{tabular}{lccccc}
\hline \multicolumn{1}{c}{ Masalah } & U & S & G & Total & Prioritas \\
\hline Karies gigi & 2 & 2 & 1 & 5 & I \\
OHIS & 1 & 0 & 2 & 3 & II \\
Struktur & 0 & 1 & 0 & 1 & III \\
Gigi(Crowded) & & & & & \\
\hline
\end{tabular}

Dari Tabel 1 diatas menunjukkan prioritas masalah prioritas utama adalah masalah karies gigi dengan skor total 5, kemudian diikuti OHIS sebagai prioritas kedua. Dan prioritas 3 adalah masalah struktur gigi.

Karies gigi terjadi karena sejumlah faktor (multiple factor) yang saling mempengaruhi yaitu tiga faktor utama yakni gigi, saliva, mikroorganisme serta substrat dan waktu sebagai faktor tambahan (Putri, dkk, 2011). Keempat faktor tersebut digambarkan sebagai lingkaran, apabila keempat faktor tersebut saling tumpang tindih maka akan terjadi karies gigi. Selain itu karies gigi juga dipengaruhi oleh faktorfaktor yang secara tidak langsung yang disebut sebagai faktor luar atau faktor eksternal yaitu perilaku, lingkungan, pelayanan kesehatan danketurunan (Notoatmodjo, 2011).

Orang tua yang memiliki anggapan tidak perlu merawat gigi anak, karena suatu saat nanti gigi anak akan tanggal dan digantikan dengan gigi tetap (Maulani, 2005). Gigi sulung pada anak pra sekolah, jika mengalami karies dan tidak dilakukan perawatan sampai karies lanjut, maka akan mengakibatkan fungsi pengunyahan dan tanggalnya gigi secara dini sehingga menyebabkan erupsi gigi permanen tidak normal (Supariani, dkk, 2013).

Hasil pemeriksaan yang telah dilakukan, menunjukkan bahwa rata-rata siswa PAUD Strowberry RW 03 Kelurahan Bangetayu Wetan memiliki nilai $\mathrm{pH}$ saliva netral dan pemeriksaan viskositas saliva termasuk dalam kategori sedang. Anak anak memiliki kebiasaan menggunakan botol saat minum susu atau ngedot, mengulum makanan saat makan, dan mengemut jari. Berbicara masalah kesehatan, beberapa orang tua responden mengaku bahwa jarang sekali untuk kontrol kesehatan gigi ke pusat pelayanan kesehatan. Hal ini dimungkinkan karena kurangnya kesadaran pada orang tua responden. Dilihat dari akses transportasi, untuk menjangkau pusat pelayanan kesehatan sangat mudah dan dekat.

Tujuan penelitian ini adalah untuk mengetahui faktor eksternal apa sajakah yang dapat menyebabkan terjadinya karies gigi pada anak pra sekolah di PAUD 
Strowberry RW 03 Kelurahan Bangetayu Wetan Semarang tahun 2016.

\section{METODE PENELITIAN}

Metode penelitian yang akan digunakan adalah metode penelitian survei deskriptif kuantitatif. Desain penelitian yang digunakan dalam penelitian ini adalah Cross Sectional, pendekatan observasi atau pengumpulan data sekaligus pada suatu saat (point time approach).

Sampel pada penelitian ini menggunakan metode total sampling atau sampel jenuh yaitu mengikutsertakan seluruh populasi yaitu siswa PAUD Strowberry RW 03 Kelurahan Bangetayu Wetan yang terkena karies, yaitu sebanyak 34 anak.

Metode analisa data yang digunakan dalam penelitian ini adalah deskriptif kuantitatif. Data dalam penelitian ini berupa data dengan skala nominal, penelitian yang menggunakan desain cross sectional, analisa faktor menggunakan program komputer atau SPSS menggunakan uji statistik Odd Ratio $(O R)$ untuk menentukan faktor penyebab yang paling dominan menyebabkan suatu kasus.Perubahan satu unit variabel pengaruh akan menyebabkan perubahan sebesar OR pada variabel pengaruh. Estimasi Confidence Interval (ECI) OR diterapkan pada tingkat kepercayaan $95 \%$ dan selalu di perlukan untuk mendampingi nilai Odd Ratio. Interval kepercayaan merupakan nilai perkiraan pada suatu titik dari suatu sampel populasi. Nilai kisaran pada satu titik daro suatu sampel mungkin tidak tepat, masih terdapat nilai kisaran, dari terendah sampai tertinggi yang masih dapat dipercaya. Interpretasi odd Ratio adalah sebagai berikut : OR $=1$ artinya faktor resiko bersifat netral, OR > 1 confient interval $(\mathrm{CI})>1$ faktor resiko penyebab penyakit, OR $<1$ faktor pelindung a/tau protektif.

\section{HASIL DAN PEMBAHASAN}

Adapun hasil penelitian di peroleh data sebagai berikut :

1. Distribusi Frekuensi

a. Karies gigi

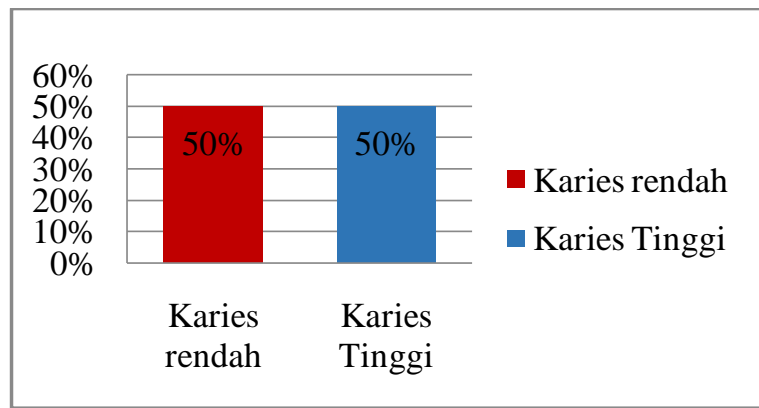

Gambar 1. Distribusi Frekuesi Karies Gigi

Berdasarkan Gambar 1 diatas dapat disimpulkan bahwa sebesar50\%anak memiliki karies dengan kategori tinggi sebesar dan 50\%. Memiliki kategori rendah. Hasil rata-rata 1 anak memiliki 10 karies gigi.

\section{b. Pengetahuan}

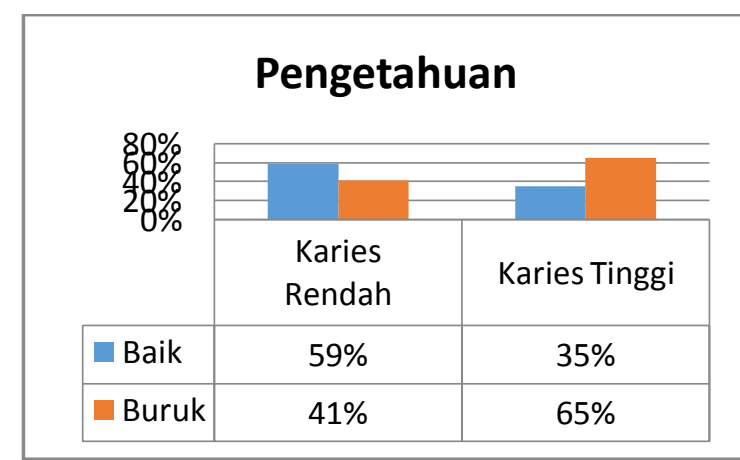

Gambar 2.Distribusi Frekuensi Hasil

Kuesioner Pengetahuan

Berdasarkan Gambar 2 diatas dapat disimpulkan bahwa responden yang memiliki pengetahuan buruk yaitu sebesar $65 \%$, pengetahuan baik yaitu sebesar 59\%. dan pengetahuan buruk yaitu sebesar $41 \%$. Dan responden dengan karies tinggi yang mempunyai pengetahuan buruk sebesar $35 \%$. 
c. Sikap

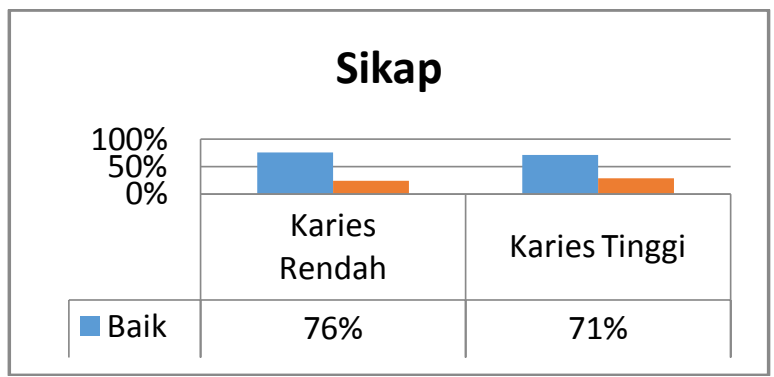

Gambar 3.DistribusiFrekuensi Hasil Kuesioner Sikap

Berdasarkan Gambar 3 diatas dapat disimpulkan responden pada kelompok karies rendah yang memiliki sikap baik sebesar $76 \%$, responden pada kelompok karies tinggi yang memiliki sikap baik sebesar $71 \%$. Responden pada kelompok karies tinggi yang memiliki sikap buruk sebesar 29\%. Dan responden pada kelompok karies rendah yang memiliki sikap buruk sebesar $24 \%$.

d. Praktik / Tindakan

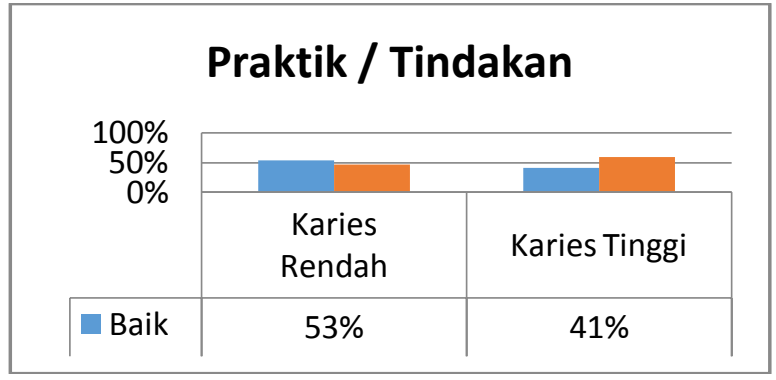

Gambar 4.DistribusiFrekuensi Hasil

Kuesioner Praktik / Tindakan

Berdasarkan Gambar 4 diatas dapat disimpulkan bahwa responden pada kelompok yang mempunyai karies tinggi dengan praktik/tindakan buruk yaitu sebesar $59 \%$. Responden yang mempunyai karies rendah dengan praktik/tindakan baik sebesar $53 \%$. Responden yang mempunyai karies rendah dengan praktik/tindakan buruk sebesar $47 \%$. responden yang mempunyai karies tinggi dengan praktik/tindakan buruk sebesar $41 \%$. e. Lingkungan

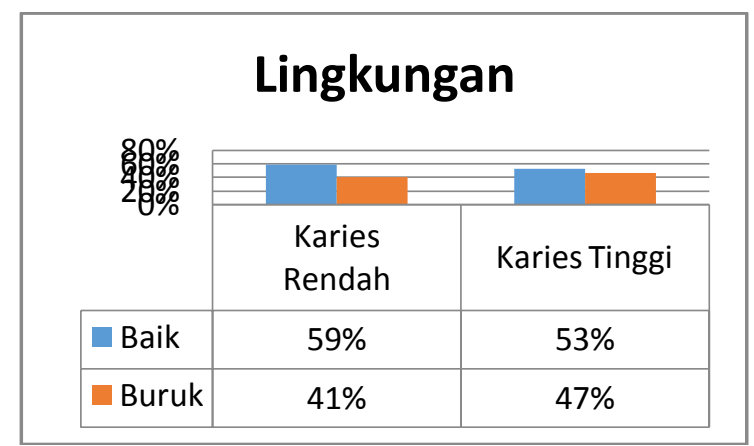

Gambar 5 DistribusiFrekuensi Hasil Kuesioner Lingkungan

Berdasarkan Gambar 5 diatas dapat disimpulkan responden pada kelompok karies rendahdengan lingkungan baik sebesar $59 \%$, responden pada kelompok karies tinggi dengan lingkungan baik sebesar 53\%. responden pada kelompok karies tinggi dengan lingkungan buruk sebesar 47\%. Dan responden pada kelompok karies rendah dengan lingkungan buruk sebesar $41 \%$.

f. Pelayanan Kesehatan

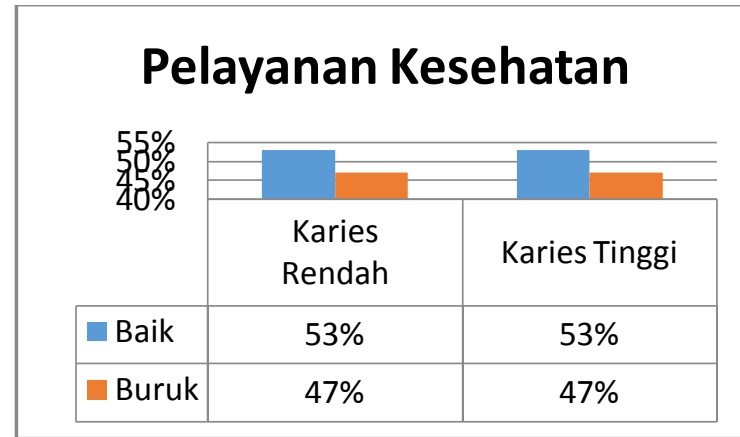

Gambar 6 Distribusi Frekuensi Hasil

Kuesioner Pelayanan Kesehatan

Berdasarkan Gambar 6 diatas dapat disimpulkan bahwa prosentase antara responden pada kelompok yang mempunyai karies rendahdengan kriteria baik dengan kelompok yang mempunyai karies tinggi dengan kriteria baik sama besarnya, yaitu $53 \%$. 
g. Keturunan

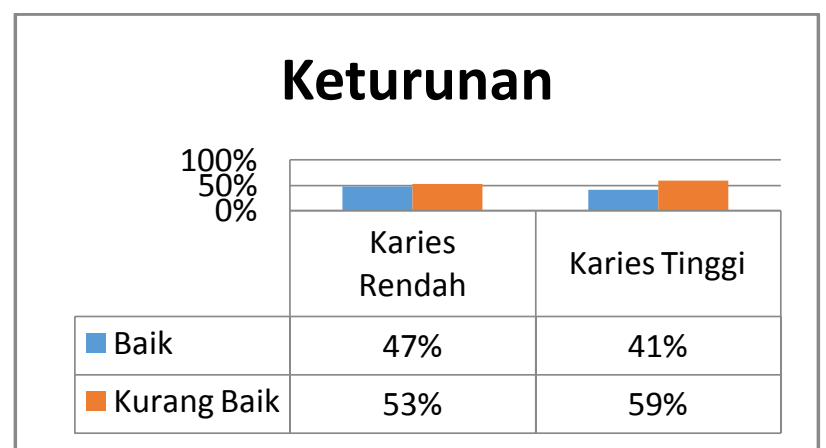

Gambar 7 DistribusiFrekuensi Hasil Kuesioner Keturunan

Berdasarkan Gambar 7 diatas dapat disimpulkan prosentase terbesar adalah responden pada kelompok karies tinggi dengan kriteria keturunan kurang baik sebesar 59\%, peringkat kedua adalah responden pada kelompok karies rendah dengan kriteria keturunan kurang baik sebesar 53\%. Kemudian pada responden pada kelompok karies rendah dengan kriteria keturunan baik sebesar 47\%. Dan yang terakhir adalah responden pada kelompok karies tinggi dengan kriteria keturunan baik sebesar $41 \%$.

\section{Analisa Penyebab Masalah}

Berdasarkan penelitian mengenai "Faktor Eksternal Penyebab Terjadinya Karies Gigi Pada Anak Pra Sekolah di PAUD Strowberry RW 03 Kelurahan Bangetayu Wetan Kota Semarang Tahun 2016"didapatkan data nilai OR dari yang tertinggi sampai yang terendah sebagai berikut :

Tabel 2. Hasil Uji Odds Ratio

\begin{tabular}{clrc}
\hline No & Variabel Pengaruh & Nilai OR & Interprestasi \\
\hline 1 & Pengetahuan & 2,619 & Penyebab \\
2 & Praktik / Tindakan & 1,607 & Penyebab \\
3 & Sikap & 1,354 & Penyebab \\
4 & Lingkungan & 1,27 & Penyebab \\
5 & Keturunan & 1,27 & Penyebab \\
6 & PelayananKesehatan & 1 & Netral. \\
\hline
\end{tabular}

\section{Perencanaan Alternatif Jalan Keluar}

Berikut adalah beberapa alternatif jalan keluar berdasarkan nilai Odds Ratio yang didapatkan :

Tabel 3. Usulan Alternatif Pemecahan Masalah

\begin{tabular}{|c|c|c|}
\hline No & $\begin{array}{l}\text { Faktor } \\
\text { Penyebab } \\
\text { Masalah }\end{array}$ & $\begin{array}{c}\text { Alternatif } \\
\text { Pemecahan Masalah }\end{array}$ \\
\hline & Pengetahuan & $\begin{array}{l}\text { a. Penyuluhan tentang kesehatan } \\
\text { gigi dan mulut } \\
\text { b. Menyikat gigi bersama di } \\
\text { sekolah }\end{array}$ \\
\hline & Praktik/Tindaka & $\begin{array}{l}\text { a. Penyuluhan tentang cara menyikat } \\
\text { gigi yang baik dan benar } \\
\text { b. Menyikat gigi bersama di } \\
\text { sekolah }\end{array}$ \\
\hline & Sikap & $\begin{array}{l}\text { a. Menyikat gigi bersama di sekolah } \\
\text { b. Penyuluhan tentang kesehatan } \\
\text { gigi dan mulut }\end{array}$ \\
\hline
\end{tabular}

Berdasarkan Tabel 3 terdapat beberapa alternatif jalan keluar yang diusulkan. Untuk mencari alternatif mana yang akan didahulukan untuk dikerjakan terlebih dahulu akan dibantu dengan teori pendekatan jalan keluar menggunakan metode Reinke. Metode Reinke merupakan metode dengan mempergunakan skor (1-5) atas serangkaian kriteria M (Magnitude), I (Importancy), $\mathrm{V}$ (Vulnerability), C (Cost). Hasil akhir adalah menggunakan rumus $=(\mathrm{M}$ x V x I) : C. Prioritas alternatif jalan keluar didapat dengan mengurutkan jumlah nilai yang tertinggi sampai terendah.

Tabel 4. Prioritas Usulan Alternatif Jalan Keluar Alternatif

Penyelesaian $\quad$ M I $\quad$ V $\quad$ C Total Prioritas Masalah

\begin{tabular}{lllllllll}
\hline Menyikat gigi bersa: & 2 & 3 & 1 & 1 & 6 & III
\end{tabular}

di sekolah

II

Penyuluhan tentang

$\begin{array}{lllllllll}\text { kesehatan gigi dan } & 3 & 2 & 3 & 1 & 18 & \text { I }\end{array}$

mulut

Penyuluhan tentang

$\begin{array}{llllllll}\text { cara menyikat gigi } & 2 & 2 & 3 & 1 & 12 & \text { II }\end{array}$

yang baik dan benar

Berdasarkan Tabel 4 prioritas pertama alternatif penyelesain masalah adalah dengan Penyuluhan tentang kesehatan gigi dan mulut. Dengan diberikan penyuluhan tentang kesehatan gigi dan mulut akan lebih peduli tentang kesehatan gigi dan 
pengetahuan tentang kesehatan gigi dan mulut akan bertambah. Sehingga diharapkan dapat mengubah perilaku menjadi baik di bidang kesehatan gigi dan mulut sehingga angka karies dapat menurun. Prioritas kedua adalah penyuluhan tentang cara menyikat gigi yang baik dan benar. Hal ini dimaksudkan agar anak-anak dapat mengetahui cara dan teknik menyikat gigi dengan benar. Prioritas yang terakhir adalah melakukan sikat gigi bersama di sekolah. Dijadikan prioritas terakhir karena sasaran telah mendapatkan penyuluhan tentang kesehatan gigi dan mulut serta penyuluhan tentang cara menyikat gigi yang baik dan benar sehingga mampu melaksanakan sikat gigi dengan baik dan benar secara bersamasama.

Hasil Odds Ratio dari keenam faktor eksternal didapatkan faktor pengetahuan memiliki nilai OR yang paling besar diantara faktor yang lain. Nilai $O R>1$ (nilai $O R=$ 2,619) berarti pengetahuan menjadi faktor resiko penyebab terjadinya karies gigi. Hasil dari kuesioner menunjukkan sebanyak 34 responden yang memiliki pengetahuan baik sebesar $47 \%$ dan responden yang memiliki pengetahuan buruk sebesar 53\%.Tingkat pengetahuan yang kurang tentang kesehatan gigi dan mulut berpengaruh terhadap karies gigi. Pengetahuan tentang gigi berlubang (76\%), upaya pengobatan gigi berlubang (71\%) dan makanan berserat (76\%) masih rendah. Sebagian besar orang tua beranggapan bahwa gigi yang berlubang pada anak-anak sudah umum terjadi dan tidak terlalu menjadi masalah yang serius. Menurut Notoatmodjo (2011) dalam Rachmawati, (2010) yang menyatakan bahwa pengetahuan merupakan suatu hasil tahu dan ini terjadi setelah sesorang melakukan pengindraan terhadap suatu obyek tertentu. Pengindraan terjadi melalui panca indera manusia, yakni penciuman, penglihatan, pendengaran, perasa dan peraba. Semakin rendah pengetahuan seseorang tentang kesehatan gigi dan mulut, maka akan semakin rendah pula tingkat kesadarannya untuk menjada dan merawat kesehatan giginya. Sehingga resiko terjadinya karies gigi akan semakin tinggi.

Hasil Odds Ratio faktor penyebab terjadinya karies gigi terbesar kedua adalah praktik / tindakan. Hasil Odd Ratio dari praktik / tindakan didapatkan nilai OR = 1,607 ini dikarenakan dari 34 responden yang memiliki praktik / tindakan baik sebesar $47 \%$ dan responden yang memiliki praktik / tindakan yang buruk sebesar 53\%. Hasil dari kuesioner menunjukkan bahwa praktik / tindakan untuk menyikat gigi dengan benar masih kurang tepat, mengurangi kebiasaan yang dapat menyebabkan gigi berlubang belum dilakukan dengan maksimal, dan masih ada beberapa orang tua yang belum rutin untuk melakukan kontrol gigi 6 bulan sekali. Semakin buruknya tindakan seseorang tentang kesehatan gigi dan mulut, maka akan semakin rendah pula tingkat kesadarannya untuk menjada dan merawat kesehatan giginya. Sehingga resiko terjadinya karies gigi akan semakin tinggi. Tindakan yang buruk dapat mempengaruhi kesehatan gigi dan mulut termasuk karies gigi (Rachmawati, 2010).

Faktor penyebab terjadinya karies gigi ketiga adalah sikap. Hasil Odds Ratio dari sikap didapatkan nilai $\mathrm{OR}=1,354$ hal ini dikarenakan dari 34 responden yang memiliki sikap baik sebesar $76 \%$ dan responden yang memiliki sikap buruk sebesar 26\%. Meskipun sebanyak 74\% responden sudah memiliki sikap yang baik, tetapi pada kenyataannya sikap menjadi salah satu faktor penyebab terjadinya karies gigi pada anak pra sekolah di PAUD Strowberry RW 03 Kelurahan Bangetayu Wetan. Sebanyak $65 \%$ orang tua setuju dengan pernyataan waktu yang tepat untuk menyikat gigi adalah setiap mandi, $76 \%$ setuju untuk tetap kontrol gigi meskipun tidak sakit. Menurut Notoatmodjo(2011) dalam Triyanti (2013) hal ini karena sikap belum merupakan suatu tindakan atau aktivitas, akan tetapi merupakan predisposisi tindakan suatu perilaku, sikap masih merupakan reaksi tertutup bukan merupakan 
reaksi terbuka atau tingkah laku yang terbuka. Sikap merupakan kesiapan untuk bereaksi terhadap obyek di lingkungan tertentu sebagai suatu pengayatan terhadap suatu obyek. Belum semua orang tua bersikap positif terhadap kejadian karies gigi, setuju dalam bersikap terhadap pentingnya mencegah karies baru. Sikap yang kurang tentang kesehatan gigi dan mulut juga dapat berpengaruh terhadap karies gigi.

Perilaku anak dalam menjaga kesehatan gigi dan mulutnya ditentukan oleh perilaku orang tuanya di rumah. Peran serta orang tua sangat diperlukan dalam membimbing, memberi pengertian, mengingatkan dan menyediakan fasilitas kepada anak agar dapat memelihara kesehatan gigi dan mulut. Saat gigi anak mulai tumbuh, terkadang orangtua belum sepenuhnya menyadari hal tersebut. Akibatnya, mereka kurang memperhatikan kebersihan rongga mulut serta gigi anak, terutama setelah makan.

Disinilah orang tua memegang peranan besar. Mereka harus mencermati segala perubahan yang mungkin timbul pada buah hatinya sehingga kemungkinan timbulnya gangguan di kemudian hari dapat dihindari (Djamil, 2011).

Hal-hal yang dapat dilakukan untuk mengatasi masalah tersebut antara lain :

1. Kegiatan Promotif

a. Penyuluhan tentang kesehatan gigi dan mulut

Penyuluhan kesehatan gigi dan mulut adalah salah satu tindakan promotif terhadap karies gigi. Penyuluhan bertujuan untuk menumbuhkan dan meningkatkan pengetahuan dan kesadaran dalam merubah perilaku dari yang belum tepat menjadi tepat yang berkaitan dengan pemeliharaan kesehatan gigi dan mulut. Penyuluhan yang diberikan antara lain :

1) Penyuluhan tentang gigi berlubang

2) Penyuluhan tentang pencegahan

3) Penyuluhan tentang diet makanan kariogenik

b. Penyuluhan tentang cara menyikat gigi yang baik dan benar
Penyuluhan tentang cara menyikat gigi yang baik dan benar untuk meningkatkan pengetahuan serta keterampilan dalam merubah perilaku menyikat gigi, waktu menyikat gigi, penggunaan sikat dan pasta gigi yang benar.

2. Kegiatan Preventif

Melaksanakan kegiatan menyikat gigi bersama di sekolah. Para siswa diajari menyikat gigi yang baik dan benar akan terbiasa melakukan sikat gigi secara mandiri dengan benar dan tepat.

\section{KESIMPULAN}

Berdasarkan hasil penelitian faktor eksternal penyebab terjadinya karies gigi pada anak pra sekolah di PAUD Strowberry RW 03 Kelurahan Bangetayu Wetan Kota Semarang Tahun 2016 dapat disimpulkan :

1. Faktor pengetahuan penyebab terjadinya karies gigi pada anak pra sekolah di PAUD Strowberry RW 03 Kelurahan Bangetayu Wetan

2. Faktor sikap penyebab terjadinya karies gigi sebesar $65 \%$

3. Faktor praktik / tindakan penyebab terjadinya karies gigi sebesar $76 \%$ anak masih memiliki kebiasaan makan coklat / permen / biskuit.

4. Faktor lingkungan penyebab terjadinya karies gigi pada anak pra sekolah sebanyak $62 \%$

5. Faktor pelayanan kesehatan penyebab terjadinya karies gigi pada anak pra sekolah sebanyak $68 \%$ anak belum pernah mendapatkan pelayanan kesehatan gigi.

6. Faktor keturunan penyebab terjadinya karies gigi pada anak pra sekolah sebanyak $65 \%$ responden menjawab kondisi gigi ibu dan anak berlubang.

\section{DAFTAR PUSTAKA}

Afrilina, G. Dan Gracinia, J., 2006, 75 Masalah Gigi Anak dan Solusinya, Jakarta: Elex Media Komputindo 
Anonim ${ }^{\mathrm{a}}$ 2015. Karies Gigi, https://id.wikipedia.org/wiki/Karies gigi, diakses tanggal 29 Desember 2015

Dahlan, S., 2011. Statistik Untuk Kedokteran dan Kesehatan. Jakarta: Salemba Medika

Depkes RI, 2013, Riset Kesehatan Dasar 2013, Jakarta: Badan Penelitian dan Pengembangan Kesehatan Republik Indonesia

Dinkes Kota Semarang, 2015, Profil Kesehatan Kota Semarang Tahun 2015, Semarang: Dinkes Kota Semarang

Djamil, M. S., 2011, A-Z Kesehatan Gigi (Panduan Lengkap Kesehatan Gigi Keluarga), Solo: Metagraf

Gunarsa, S. D., 2008, Psikologi Perkembangan Anak dan Remaja. Jakarta: PT. BPK Gunung Mulia

Kidd, E., dkk, 2013, Dasar - Dasar Karies, Jakarta: EGC

Maulani, C., 2005, Kiat Merawat Gigi Anak, Jakarta: PT. Elek Media Komputindo

Notoadmodjo, S., 2003, Pendidikan dan Perilaku Kesehatan, Jakarta: Rineka Cipta

Notoadmodjo, S., 2011, Kesehatan Masyarakat Ilmu dan Seni Edisi Revisi 2011, Jakarta: Rineka Cipta

Notoadmodjo, S., 2012, Metodologi Penelitian Kesehatan, Jakarta: Rineka Cipta

Pontonuwu, J., Mariati, N. W., danWicaksono, D., 2014, Gambaran Status Karies Anak Sekolah Dasar di Kelurahan Kinilow 1 Kecamatan
Tomohon Utara, Manado: Jurnal Kedokteran Gigi Fakultas Kedokteran Universitas Sam Ratulangi Manado

Putri, M.H., Herijulianti, E., danNurjannah, N., 2011, Ilmu Pencegahan Penyakit Jaringan Keras dan Jaringan Pendukung Gigi, Jakarta: EGC

Rachmawati, N., 2010. Faktor -Faktor Eksternal Penyebab Terjadinya Karies Gigi Pada Siswa TK Averrous Desa Bangsri Kecamatan Bangsri Kabupaten Jepara. Laporan Studi Kasus Jurusan Keperawatan Gigi Poltekkes Kemenkes Semarang

Saryono, 2011, Metodologi Penelitian Kesehatan, Yogyakarta: Nuha Medika

Sugiyono. 2007. Metode Penelitian Kuantitatif, Kualitatif dan $R \& D$. Bandung: Alfabeta

Supariani, Ni Nyoman., dkk, 2013, Hubungan Karbohidrat pada Susu yang Dikonsumsikan dengan Kejadian Karies Botol pada Anak Play Group, Denpasar: Jurnal Kesehatan Gigi Vo. 1 No. 1 Poltekkes Denpasar

Tarigan, R., 2013, Karies Gigi Edisi 2, Jakarta: EGC

Triyanti, A., 2013, Faktor-Faktor Penyebab Terjadinya Karies Gigi Pada Anak TK di Wilayah Kerja Binaan Puskesmas Karangayu Kota Semarang. Laporan Studi Kasus Jurusan Keperawatan Gigi Poltekkes Kemenkes Semarang

UU No. 36 Tahun 2014 Tentang Tenaga Kesehatan Tambahan Lembaran Negara Republik Indonesia Nomor 5607 